\title{
Is the state really a Leviathan? Testing the model of Buchanan and Brennan in Europe
}

\section{Introduction}

People generally ascribe many negative attributes to government action. Bureaucracy is seen as an ineffective mechanism of coordinating public action, and public officials are often suspected of fraudulent and even corrupt actions. One of the most influential theoretical approaches that assumes extremely egoistic behavior on the part of government representatives is that put forward by G. Brennan and J.M. Buchanan (2000) in their State-as-Leviathan model. It suggests that the main goal of people acting within the government sphere is to maximize government revenue, putting unnecessarily high costs on the governed. But is it really the case that government acts in this kind of simplistic way without taking the good of the society into its "utility function"? This article tries to answer that question using data from the latest edition of the European Social Survey. In the first part, the main assumptions of the model are described. In the second, the model is developed further in order to present main research hypotheses. In the third part, the critique and remarks on the model are reviewed. The fourth part is devoted to developing an empirical model and presenting the main findings of the analysis. The summary concludes the text with some suggestions for future research. The conducted analysis allows us to draw conclusions pointing at the less-thanperfect ability of the Leviathan model to describe real events in the areas of fiscal policy and taxation, and in some instances seems to corroborate the conclusions ascribed to the "orthodox" theory of public finance criticized by G. Brennan and J.M. Buchanan.

\footnotetext{
* Author is a doctoral candidate in the Cracow University of Economics (CUE)
} 


\section{Model assumptions}

The Leviathan model is a response to a group of theories that can be jointly described as optimal taxation theories (Samuelson 1947, Musgrave 1959). With some simplification, one can say that optimal taxation theories assume the state should utilize as broad a tax base as it can. It is so due to the tendency of individuals to substitute an activity which is more useful/productive, but subject to taxation, with an activity of less usability, but free from tax.. As a consequence of the described substitution process, the necessity of imposing high taxes on a limited number of sources causes social loss in the form of a so-called excess tax burden. A theoretical ideal that efficiency of different tax systems is compared to is called a lump-sum tax or poll tax. But as it seems unattainable, the real-life alternative that is being considered as a second-best solution amounts to postulate that, besides work or income, the state should tax goods and services that are complementary to leisure as a way to discourage citizens from substituting productive activity (work) with unproductive activity. In consequence, to reach a particular level of revenue, the state would be able to levy taxes that are less distortionary which would worsen the citizen's situation to a lesser extent (in economic terms, will move it to a higher indifference curve) than in the case of a narrow tax-base.

G. Brennan and J.M. Buchanan are criticizing this group of theories (calling them "orthodox" theories) by raising doubts as to an assumption that the state aims for some preordained level of revenue and is considering only how to secure it in an optimal way. Using an assumption similar to William Niskanen (1971) - and explicitly citing his work - they state that there is no bound for the rapacity of actors functioning within the government. They will only try to assess what is the lowest indifference curve they can move the citizen to, with little political consequence, and they will use any tool at their disposal to secure as much revenue as they can within this constraint. In consequence of this conclusion, the authors try to explain in their opinion a rational behavior of citizens faced with “constitutional choice”, behind Rawlsian's (1971) "veil of ignorance". They state that the individual will assume an optimal amount of public goods from the perspective of entire society and will try to constrain the taxing authority in such a way that it will capture no more resources than is necessary to secure that particular amount of public goods.

A simple formula describing the optimal amount of public goods from the perspective of the representative taxpayer assumes that only some part of government revenue will finance productive public goods. According to Leviathanmodel assumptions, the government will act to maximize the amount of tax 
revenue $R$ given the tax base $(b)$ and the structure of tax rates $(r)$. So the problem that an individual under the constitutional choice framework faces is to estimate the levels of $b$ and $r$, which generate the amount of revenue collected by the state that is sufficient but does not exceed the amount needed to finance the optimal level of public goods.

According to the model, if a society faced with constitutional choice won't restrict the ability of the state to levy taxes through introducing constraints on the broadness of the tax base, forbidding to levy regressive taxes (and optimally forcing the state to use progressive instruments), and constraining the level of maximum tax rate, it has to face the consequences with the state accumulating too much revenue through the tax system than is optimal in the constitutional framework.

\section{The model - consequences of different constraints on the tax base and the structure of tax rates}

Figure 1 shows the consequences of assuming a different breadth of taxable base (levying tax on work, leisure, or both) under the Leviathan model.

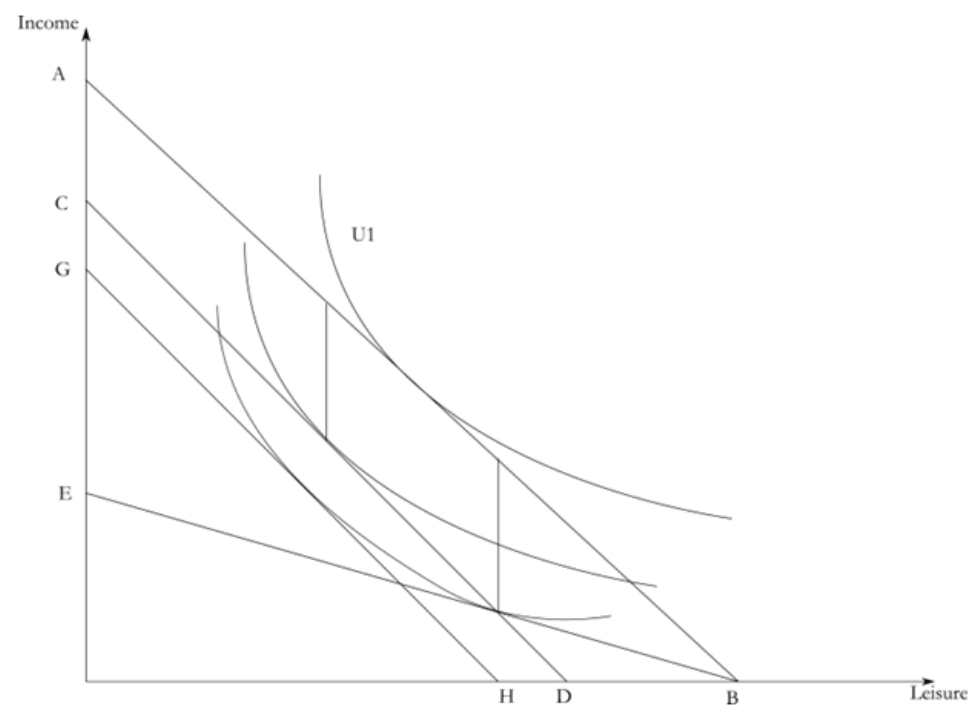

Figure 1. Consequences of using different taxable bases Source: (Mueller 2003, pp. 381) 
The figure exemplifies a situation in which the government is assumed to be forced to acquire AC level of tax revenue from taxpayers. In order to achieve this goal, it can levy different taxes. Let's imagine that it is possible to levy taxes both on income and on leisure (in the form of, let's say, tax on the "potential" to earn income). Then, it is enough for the state to reduce the income of the taxpayer by moving his budget constraint from $\mathrm{AB}$ to $\mathrm{CD}$. Classical tax theory assumes this kind of situation to be optimal, because economic incentives are not disturbed and the government is able to secure a given amount of revenue without overly diminishing the utility of the taxpayer. However if, due to some reasons (technical or legal constraints) the government is able to levy tax only on income (in the form of e.g. PIT), than in order to secure the same amount of revenue it has to levy a tax in the amount of AE. This moves the taxpayer to the still lower indifference curve tangent to the budget constraint line EB. Conclusion? If the government wanted to maximize its social welfare function, it should be given unconstrained possibilities as to the breadth of the tax base. However, according to the model under discussion, the motivation of the government is different. At the beginning, it tries to evaluate on which lowest indifference curve it is able to move the citizen without losing his/her support, and then attempts to levy such taxes to maximise its tax take (revenues). In such a situation, if it knows that the lowest indifference curve the tax-payer will endure is the one tangent to the budget constraint curve EB, and it has the ability to levy taxes both on income and leisure, it is able to move the budget constraint curve to the GH level and acquire revenues in the amount of AC. Then (assuming correctness model assumptions), if we as taxpayers and voters want to lower the possibility for the government to maximize its tax take, we should force it to mandate by law to lower the amount of tax instruments that stay at its disposal. There are empirical proofs, that authorities who are given fewer possibilities to levy taxes generate lesser budgetary revenue and, as a consequence, lesser public sphere on that basis.

Let's turn now to the consequences of imposing a different structure of tax rates, as shown in Figure 2.

The curve DD shows the demand of a person for an activity yielding profit. A negative slope may be a consequence of the diminishing marginal utility of work relative to leisure effect and may be derived using the preference map presented in figure 1. Assuming that only proportional tax is at the government's disposal, what rate will be set up? Following this interpretation is analogous to considerations concerning a monopolistic profit-maximizing entity. In Figure 1, one can draw a "marginal revenue" curve (MR). The amount of $Y$ (in this instance, this represents time devoted to productive work) that maximizes government revenue is derived from the point of intersection between the MR curve and the "marginal cost" of acquiring another zloty curve (MC). 


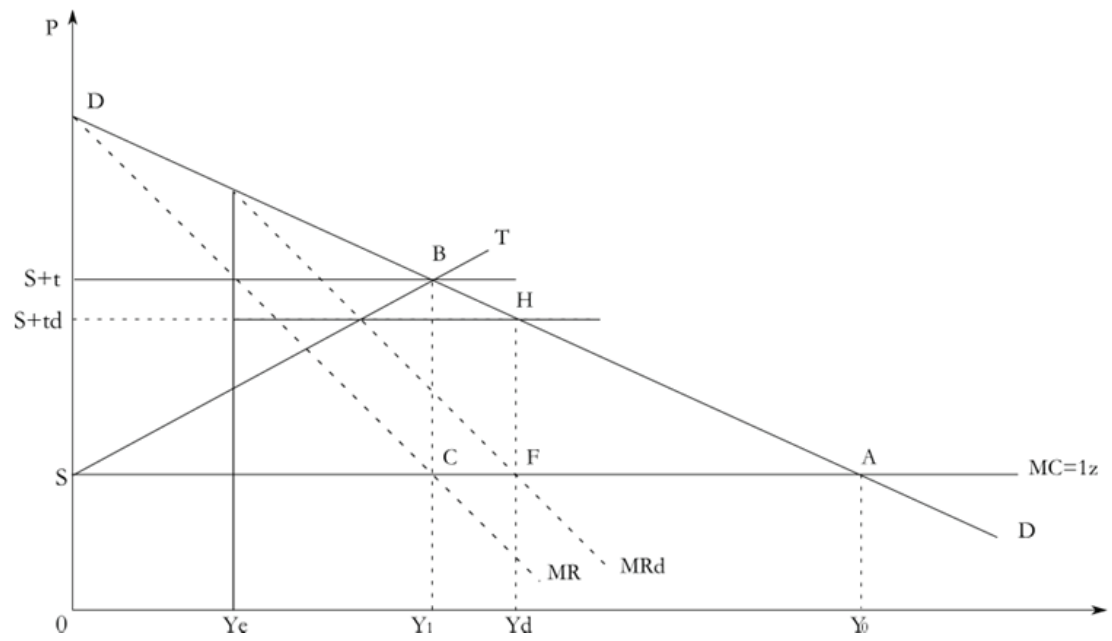

Figure 2. Tax rates and Leviathan revenue

Source: (Brennan, Buchanan 2000, pp. 52)

Using simple algebra, it can be easily shown that the maximum revenue of the Leviathan is proportional to the initial size of the taxable base, and inversely proportional to the elasticity of "production" relative to its "price". It is easy to show that $Y_{0}=2 Y_{1}$ and the social loss (shown in the figure as the ABC triangle) from this form of taxation assuming linear functions is equal to exactly half the amount of government revenue.

If the government is allowed to use a regressive rate. it is able to capture all of the social surplus from work (interestingly, we don't have any social loss in this situation - this constitutes an "effective" arrangement).

On the other hand, it is important to consider the consequences of utilizing a progressive rate of taxation. Leviathan is not interested in imposing such a scheme because it should in principle reduce its revenue. The simplest way of introducing progressive taxation is excluding a part of income from taxation (taxexempt amount - this kind of tax is sometimes called degressive). Looking again at figure 2, let's assume that the amount of exemption is equal to Ye. Above this amount, we use a proportional rate. The new curve of marginal revenue is $M R d$. In this scheme, the rate that maximizes revenue is $\mathrm{td}$. Revenue drops from " $t Y_{1}$ " to " $t d^{*}(Y d-Y e)$ ". The triangle showing the amount of social loss from taxation is now AFH. Its area decreases relative to the triangle $\mathrm{ABC}$.

As Buchanan and Brennan point out, not all forms of progression are beneficial for the taxpayer (but all, ceteris paribus decrease governments revenue). 
For instance, a perfect progression (as shown by the ST curve in the Figure 2) if it leads to utilizing the marginal rate of revenue equal $t$ for the Y1 amount of "production", will halve the possible revenue with the same social loss, but this constitutes a somehow restricted case.

In consequence of the preceding analysis, we can try to develop three testable hypotheses:

H1: Broadening of the tax-base leads to the rise of government revenue.

H2: A broad tax-base, shifting the relation between the size of the public relative to private sphere, is considered unfavourable by members of the society.

H3: Progressive taxation normally decreases the social loss from taxes and, consequently, is considered advantageous by members of society.

\section{Empirical work and the model critique}

The State-as-Leviathan theory had some empirical following corroborating its propositions to some extent. Research conducted in New Hampshire by Campbell (1994) suggest that limitations in terms of the broadness of the tax-base and the level of maximum tax-rate have a negative influence on the level of taxation and the amount of generated revenue. He has shown that the population of New Hampshire rises faster than in other states, suggesting that citizens of the US vote with their feet on such restrictions of the fiscal authority of the state.

M.A. Nelson (1986) shows that the use of a broader taxable base generally leads to a rise in government revenues. Similar results are presented by J. Rodden (2003). In line with the fiscal competition theory developed on the basis of the State-as-Leviathan model, R.T. Deacon (1979), S.L. Mehay (1984), D.R. Cameron (1978), R. Santolini (2009), M. Schneider (1986), and others show that an increase in the possibility of fiscal competition between municipalities leads to a decrease in the tax-take of those entities. On the other hand, W.E. Oates (2003) doesn't find enough evidence to corroborate the State-asLeviathan model. Recent studies unrelated to the theory conducted by e.g., S. Oishi et al. (2012) show that the progressive tax system indeed positively influences life-satisfaction of the citizens.

The Buchanan-Brennan concept was obviously also strongly criticised. The explanation of the less-than-perfect ability of the model in explaining life satisfaction probably rests in the fact that only a slight weakening of the model's assumptions forces one to its re-evaluation, both on theoretical and empirical grounds. Even a brief look at figure 1 and its interpretation leads one to 
ask a question: if no matter how broad the tax base the government will shift me to the same indifference curve, and if some even miniscule part of every penny gained by it will finance productive public goods, won't I find myself in better situation if the broader base is implemented? And even assuming that all additional revenue will be used by the representatives of the state for their own private whims, shouldn't the broadness of the tax base be indifferent to me (which stems from the very definition of the "indifference curve")? The critique emphasizing the existence of "productive" public goods (and from the "orthodox" perspective of incentive disturbance) was put forward by T. Apolte (2007) in the text with the provocative title: Why Brennan and Buchanan are wrong (after all). From the vantage point of the costs of decreasing the domain of the state, the critique was also put forward by La Manna and Slop (1994), among others.

\section{The design and results of the empirical model}

Utilizing the European Commission base "Taxes in Europe - Taxreforms" (TEDB/TAXREF) that includes information on all tax instruments ${ }^{1}$ currently used by European countries, the proxy for the broadness of the tax base was derived. From the Eurostat base, the information on the GDP level, GDP growth, general government revenue, and deficits was acquired. The variables on the satisfaction of citizens with life in general,on the satisfaction with the activities of the national government and some control variables were taken from the latest European Social Survey, 2012 edition. On that basis, two OLS models were constructed. Basic forms of the models are shown below.

$$
\begin{aligned}
& L \_\mathrm{SAT}_{\mathrm{ij}}=\alpha_{\mathrm{i}}+\beta_{0} \ln \_t a x \_q_{j}+\beta_{1} G R O W T H_{j}+\beta_{2} R E V_{j}+ \\
& +\beta_{3} \text { flat_tax }{ }_{j}+\beta_{4} \ln \text { GDP }_{j}+\mu_{i j} \\
& G_{-} S A T_{i j}=\alpha_{\mathrm{i}}+\beta_{0} \ln \_t a x \_q_{j}+\beta_{1} G R O W T H_{j}+\beta_{2} R E V_{j}+ \\
& +\beta_{3} \text { flat_tax }+\beta_{4} \ln \_G D P_{j}+\mu_{i j}
\end{aligned}
$$

where $L \_S A T_{i j}$ is the satisfaction of an " $i$ " citizen of the " $j$ " country measured by the response to the question from the ESS survey: "How satisfied are you with life in general?". $G_{-} S A T_{i j}$ is the satisfaction of an " $i$ " citizen of the " $j$ " country measured

${ }^{1}$ All the taxes (excise, tolls, direct and indirect taxes, luxury and gambling taxes and financial taxes) figuring in the database were used on an indiscriminatory basis. 
by the response to the question from the ESS survey: "How satisfied with national government are you?". The variable $\ln \_\operatorname{tax} q_{j}$ corresponds to the number of tax instruments used in the " $j$ " country in the year 2012 (natural logarithm is used because of assumed decreasing marginal revenue of the amount of tax instruments, and because the author assumes that the more tax instruments exist in a particular country, the less peoples life satisfaction is affected by the marginal

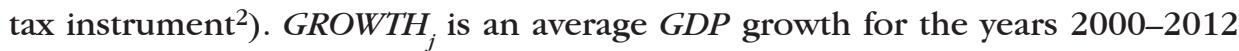
for the country " $j$ ". $R E V_{j}$ is the average general government revenue for the country " $j$ " in the years 2000-2012. The variable flat_tax is a dummy showing the existence of proportional income taxation in country " $j$ ". The variable $l n_{-} G D P$ is a natural logarithm of the level of GDP compared to the EU average for the country " $j$ " in the year 2012 .

Table 1 shows the values of basic chosen variables for 28 EU countries and whether they participated in the ESS 2012 survey.

Table 1

Basic data for the EU countries

\begin{tabular}{|l|c|c|c|c|c|c|}
\hline Country & $\boldsymbol{t a x} \mathbf{q}$ & GROWTH & $\boldsymbol{R E V}$ & flat_tax & GDP** & ESS 2012 \\
\hline Austria & 40 & 1,75 & 51,1 & 0 & 127 & 0 \\
\hline Belgium & 38 & 1,50 & 50,9 & 0 & 119 & 1 \\
\hline Bulgaria & 26 & 3,83 & 38,4 & 1 & 44 & 1 \\
\hline Cyprus & 35 & 2,42 & 42,8 & 0 & 97 & 1 \\
\hline Czech Republic & 37 & 3,01 & 43,7 & 0 & 80 & 1 \\
\hline Denmark & 80 & 0,82 & 54,8 & 0 & 128 & 1 \\
\hline Estonia & 13 & 4,59 & 36,8 & 0 & 63 & 1 \\
\hline Finland & 41 & 1,94 & 51,2 & 0 & 113 & 1 \\
\hline France & 43 & 1,30 & 54,0 & 0 & 108 & 0 \\
\hline Germany & 44 & 1,31 & 46,3 & 0 & 119 & 1 \\
\hline Greece & 28 & 0,92 & 48,2 & 0 & 87 & 0 \\
\hline Hungary & 52 & 1,88 & 49,9 & 1 & 65 & 1 \\
\hline Ireland & 40 & 3,12 & 39,7 & 0 & 127 & 1 \\
\hline Italy & 66 & 0,43 & 48,6 & 0 & 101 & 0 \\
\hline Latvia & 24 & 4,37 & 37,7 & 1 & 54 & 0 \\
\hline Lithuania & 29 & 4,57 & 37,2 & 1 & 61 & 0 \\
\hline
\end{tabular}

2 It have to be said still, that using the $t a x \_g$ instead of $l_{n} t_{-} t a x_{-} q$ in the regressions leads to similar results to those presented in the article. 
Is the state really a Leviathan? Testing the model of Buchanan and Brennan in Europe

Table 1 cont.

\begin{tabular}{|l|c|c|c|c|c|c|}
\hline Luxembourg & 33 & 2,92 & 41,0 & 0 & 267 & 0 \\
\hline Malta & 32 & 1,68 & 42,5 & 0 & 86 & 0 \\
\hline Netherlands & 26 & 1,31 & 47,2 & 0 & 131 & 1 \\
\hline Poland & 29 & 3,82 & 43,4 & 0 & 63 & 1 \\
\hline Portugal & 19 & 0,48 & 45,9 & 0 & 80 & 1 \\
\hline Romania & 51 & 3,68 & 37,0 & 1 & 47 & 0 \\
\hline Slovak Republic & 32 & 4,26 & 40,1 & 0 & 73 & 1 \\
\hline Slovenia & 23 & 2,32 & 46,4 & 0 & 84 & 1 \\
\hline Spain & 28 & 1,92 & 41,3 & 0 & 99 & 1 \\
\hline Sweden & 55 & 2,38 & 53,5 & 0 & 124 & 1 \\
\hline United Kingdom & 50 & 1,72 & 44,3 & 0 & 111 & 1 \\
\hline Croatia & 26 & 2,08 & $46,6 *$ & 0 & 58 & 0 \\
\hline
\end{tabular}

* data for the years 2009-2012, ** where 100 is an average for $28 \mathrm{EU}$ countries

Source: TEDB/TAXREF, Eurostat, ESS 2012

On the basis of the acquired data, first the $\mathrm{H} 1$ was tested by conducting the simple Pearson correlation between the proxy for tax-base broadness ( $\left.\ln \_t a x \_q^{3}\right)$ and general government revenue $(R E V)$. Due to a small sample of countries, the only correlation was attempted to look for significance of the link between the variables. Despite the small sample, the correlation coefficient was positive (0.412) and significant with the value of $p$ not exceeding 0.05 . It is thus shown that there is a positive relationship between the variables, attesting to the validity of both the State-as-Leviathan model and the commonsensical intuition. An OLS-robustness check was conducted by adding flat-tax and GDP variables in one specification and flat_tax plus $\ln \_G D P$ in a second specification. The coefficient besides the $\ln \_t a x \_q$ variable remained positive but lost its significance $(p<0,07$ and $p<0.11$ respectively). While we cannot state that this attests to a robust relationship, we have to bear in mind the extremely small sample used for the regression.

To test the latter two hypotheses, the $O L S$ tool was used. The analysis was conducted for 18 countries participating in the ESS 2012 from the preliminary

3 As stated earlier author assumes a decreasing positive influence of the marginal tax instruments on the government revenue. When using flat_tax instead of $l n \_f l a t$ tax as a variable in the correlation the correlation coefficient is even higher 
pool. Results of two analyses (one with the dependent variable corresponding to general life satisfaction and one with dependent variable corresponding to satisfaction with the government) are shown in Tables 2 and 3.

Table 2

Regression coefficients, dependent variable "How satisfied with life as a whole"

\begin{tabular}{|c|c|c|c|c|c|}
\hline \multirow{2}{*}{ Variable } & \multicolumn{5}{|c|}{ Model no. } \\
\hline & (1) & (2) & (3) & (4) & (5) \\
\hline GROWTH & $\begin{array}{c}0.19^{* * * *} \\
(0.02)\end{array}$ & $\begin{array}{c}0.09^{* * * *} \\
(0.02)\end{array}$ & $\begin{array}{l}0.04^{* *} \\
(0.02)\end{array}$ & $\begin{array}{c}0.00 \\
(0.02)\end{array}$ & $\begin{array}{c}-0.07^{* * * *} \\
(0.02)\end{array}$ \\
\hline$R E V$ & $\begin{array}{l}0.09^{* * * *} \\
(0.00)\end{array}$ & $\begin{array}{l}0.06^{* * * *} \\
(0.00)\end{array}$ & $\begin{array}{l}0.05^{* * * *} \\
(0.02)\end{array}$ & $\begin{array}{l}0.05^{\text {**** }} \\
(0.00)\end{array}$ & $\begin{array}{l}0.02^{\text {**** }} \\
(0.00)\end{array}$ \\
\hline flat_tax & $\begin{array}{c}-1.54^{* * * *} \\
(0.06)\end{array}$ & $\begin{array}{c}-1.69^{* * * * k} \\
(0.06)\end{array}$ & $\begin{array}{c}-1.62^{* * * *} \\
(0.06)\end{array}$ & $\begin{array}{c}-1.71^{* * * *} \\
(0.06)\end{array}$ & $\begin{array}{c}-1.70^{* * * *} \\
(0.06)\end{array}$ \\
\hline ln_tax_q & $\begin{array}{l}0.30^{* * * *} \\
(0.05)\end{array}$ & $\begin{array}{l}0.49^{* * * *} \\
(0.05)\end{array}$ & $\begin{array}{l}0.38^{* * *} \\
(0.05)\end{array}$ & $\begin{array}{l}0.35^{* * *} \\
(0.05)\end{array}$ & $\begin{array}{c}0.39^{* * *} \\
(0.05)\end{array}$ \\
\hline ln_GDP & $\begin{array}{l}1.08^{* * * *} \\
(0.08)\end{array}$ & $\begin{array}{l}0.80^{* * * *} \\
(0.09)\end{array}$ & $\begin{array}{l}1.05^{* * * *} \\
(0.09)\end{array}$ & $\begin{array}{l}0.77^{* * * *} \\
(0.09)\end{array}$ & $\begin{array}{c}0.10 \\
(0.09)\end{array}$ \\
\hline$D E F$ & $\mathrm{X}$ & $\begin{array}{l}0.06^{* * * *} \\
(0.01)\end{array}$ & $\begin{array}{l}0.04^{* * *} \\
(0.01)\end{array}$ & $\begin{array}{l}0.04^{* * *} \\
(0.01)\end{array}$ & $\begin{array}{l}0.01^{* * *} \\
(0.01)\end{array}$ \\
\hline PIGS & $\mathrm{X}$ & $\mathrm{X}$ & $\begin{array}{c}-0.44^{* * * *} \\
(0.04)\end{array}$ & $\begin{array}{c}-0.37^{* * * *} \\
(0.04)\end{array}$ & $\begin{array}{c}-0.27^{* * * *} \\
(0.04)\end{array}$ \\
\hline eduyrs & $\mathrm{X}$ & $\mathrm{X}$ & $\mathrm{X}$ & $\begin{array}{l}0.05^{\text {*** }} \\
(0.00)\end{array}$ & $\begin{array}{c}0.03^{* * * *} \\
(0.00)\end{array}$ \\
\hline soc_pol_cap & $\mathrm{X}$ & $\mathrm{X}$ & $\mathrm{X}$ & $\mathrm{X}$ & $\begin{array}{l}0.63^{* * * *} \\
(0.01)\end{array}$ \\
\hline Constant & $\begin{array}{c}-3.29^{* * * *} \\
(0.35)\end{array}$ & $\begin{array}{c}-1.10^{* * * * *} \\
(0.42)\end{array}$ & $\begin{array}{c}-0.95^{* *} \\
(0.42)\end{array}$ & $\begin{array}{l}-0.42 \\
(0.42)\end{array}$ & $\begin{array}{l}4.10^{* * *} \\
(0.43)\end{array}$ \\
\hline$N$ & 34111 & 34111 & 34111 & 33870 & 29108 \\
\hline Corr. $R^{2}$ & 0.171 & 0.174 & 0.177 & 0.185 & 0.232 \\
\hline
\end{tabular}

* confidence level $<0.1, * *$ confidence level $<0.05, * * *$ confidence level $<0.01$ $\mathrm{X}$ - variable not considered in a model Std. err. in parentheses 
Is the state really a Leviathan? Testing the model of Buchanan and Brennan in Europe

Table 3

Regression coefficients, dependent variable "How satisfied with the national government"

\begin{tabular}{|c|c|c|c|c|c|}
\hline \multirow{2}{*}{ Variable } & \multicolumn{5}{|c|}{ Model no. } \\
\hline & (1) & (2) & (3) & (4) & (5) \\
\hline GROWTH & $\begin{array}{c}0.71^{* * * *} \\
(0.02)\end{array}$ & $\begin{array}{l}0.41^{* * *} \\
(0.02)\end{array}$ & $\begin{array}{l}0.28^{* * *} \\
(0.02)\end{array}$ & $\begin{array}{l}0.26^{* * * *} \\
(0.02)\end{array}$ & $\begin{array}{l}0.14^{* * * *} \\
(0.02)\end{array}$ \\
\hline$R E V$ & $\begin{array}{l}0.19^{* * * *} \\
(0.00)\end{array}$ & $\begin{array}{l}0.11^{* * * * *} \\
(0.01)\end{array}$ & $\begin{array}{l}0.07^{* * * *} \\
(0.01)\end{array}$ & $\begin{array}{l}0.07^{* * * *} \\
(0.01)\end{array}$ & $\begin{array}{l}0.03^{* * * *} \\
(0.01)\end{array}$ \\
\hline flat_tax & $\begin{array}{l}0.90^{* * * *} \\
(0.07) \\
\end{array}$ & $\begin{array}{l}0.44^{* * * *} \\
(0.07) \\
\end{array}$ & $\begin{array}{l}0.63^{* * * *} \\
(0.07) \\
\end{array}$ & $\begin{array}{l}0.58^{* * * *} \\
(0.07)\end{array}$ & $\begin{array}{l}0.39^{* * * *} \\
(0.06) \\
\end{array}$ \\
\hline In_tax_q & $\begin{array}{c}-0.65^{* * *} \\
(0.05) \\
\end{array}$ & $\begin{array}{c}-0.12^{* * *} \\
(0.06) \\
\end{array}$ & $\begin{array}{c}-0.39^{* * * *} \\
(0.06) \\
\end{array}$ & $\begin{array}{c}-0.42^{* * *} \\
(0.06) \\
\end{array}$ & $\begin{array}{c}-0.32^{* * * *} \\
(0.09) \\
\end{array}$ \\
\hline ln_GDP & $\begin{array}{l}2.00^{* * * *} \\
(0.09) \\
\end{array}$ & $\begin{array}{l}2.17^{* * * *} \\
(0.10) \\
\end{array}$ & $\begin{array}{l}2.81^{* * * *} \\
(0.10) \\
\end{array}$ & $\begin{array}{l}2.67^{* * * *} \\
(0.10) \\
\end{array}$ & $\begin{array}{c}1.11 \\
(0.01) \\
\end{array}$ \\
\hline$D E F$ & $\mathrm{X}$ & $\begin{array}{l}0.18^{* * * *} \\
(0.01) \\
\end{array}$ & $\begin{array}{l}0.12^{* * * *} \\
(0.01) \\
\end{array}$ & $\begin{array}{l}0.12^{* * * *} \\
(0.01) \\
\end{array}$ & $\begin{array}{l}0.02^{* * *} \\
(0.01) \\
\end{array}$ \\
\hline PIGS & $\mathrm{X}$ & $\mathrm{X}$ & $\begin{array}{c}-1.12^{* * * *} \\
(0.04)\end{array}$ & $\begin{array}{c}-1.01^{* * *} \\
(0.04) \\
\end{array}$ & $\begin{array}{c}-0.87^{* * * *} \\
(0.04)\end{array}$ \\
\hline eduyrs & $\mathrm{X}$ & $\mathrm{X}$ & $\mathrm{X}$ & $\begin{array}{l}0.03^{* * * *} \\
(0.00) \\
\end{array}$ & $\begin{array}{c}-0.02^{* * * *} \\
(0.00)\end{array}$ \\
\hline soc_pol_cap & $\mathrm{X}$ & $\mathrm{X}$ & $\mathrm{X}$ & $\mathrm{X}$ & $\begin{array}{l}1.51^{* * * *} \\
(0.01) \\
\end{array}$ \\
\hline Constant & $\begin{array}{c}-17.70^{* * * *} \\
(0.40) \\
\end{array}$ & $\begin{array}{c}-11.21^{* * * k} \\
(0.47)\end{array}$ & $\begin{array}{c}-10.76^{* * * *} \\
(0.47)\end{array}$ & $\begin{array}{c}-10.47^{* * * *} \\
(0.47)\end{array}$ & $\begin{array}{c}-1.04^{* * *} \\
(0.42) \\
\end{array}$ \\
\hline$N$ & 33327 & 33327 & 33327 & 33097 & 28844 \\
\hline Corr. $R^{2}$ & 0.130 & 0.146 & 0.163 & 0.164 & 0.437 \\
\hline
\end{tabular}

$*$ confidence level $<0.1, * *$ confidence level $<0.05, * * *$ confidence level $<0.01$

$\mathrm{X}$ - variable not considered in a model

Std. err. in parentheses

Source: own compilation

Analysis of the results shows that progressive taxation generally increases life satisfaction of citizens (corroborating H3), which is in line with previous research. At the same time, interestingly, a proportional tax seems to increase satisfaction from the government. Larger general-government revenue seems to have a consequently positive impact on both measures of citizen satisfaction (but the 
coefficient in not high ${ }^{4}$. The broadness of the tax base as an explanatory variable for the two dependent variables behaves similarly to progressive taxation: it decreases satisfaction with government (in line with H2) and increases satisfaction with life in general (against $\mathrm{H} 2$ and in line with economic orthodoxy). Basic control variables ( $\ln$ G GDP and GROWTH) behave coherently, with both having a positive influence on the satisfaction measures

To test the robustness of the model, first the $D E F$ variable (the average general government deficit for the years 2000-2012) was introduced followed by the PIGS variable (dummy for Ireland, Portugal, and Spain), and the variables from the ESS survey: full years of completed education (eduyrs) and seven variables attesting for the trust in national and international institutions ${ }^{5}$. In one of the models, the "trust variables" due to the concern of collinearity were merged in one variable through the Principal Factor Analysis (soc_pol_cap). All of the models show consistent results, suggesting that the observed causal link is significant and robust.

Specifically, the somewhat "erratic" behavior of the flat_tax and $\ln \_t a x \_q$ variables needs an explanation. In the author's view, a positive influence of a narrower tax base and proportional taxation on satisfaction with the government stems from the fact that they are seen by the citizens as simple, leaner rules. On the other hand, their negative impact on satisfaction of life as a whole suggests that rules otherwise considered complex may lead to a government that serves the needs of its citizens better, and is able to do so using a less distortionary tax system. So in the author's view, one should carefully embrace the $\mathrm{H} 3$ and reject the $\mathrm{H} 2$. All in all, this problem requires further research.

\section{Conclusion}

The State-as-Leviathan model is interesting due to several reasons, among which possibly the most important and most perverse seems to be that, while looking for constitutional rules that are going to restrict the possibility of power abuse, it supports the notion of progressive taxation, normally attributed to the political left. It is, however, based on some controversial assumptions which limit its usefulness in practice. Nonetheless, it gives the possibility of constructing simple and

4 Alternative specification not shown in the paper which uses $l n \_R E V$ instead of $R E V$ the coefficients are substantially positive and significant. This doesn't change the rest of the results in any significant way. The $R E V$ was used on an arbitrary basis taking note that the variable was already presented in terms relative to the size of the economy.

5 The results of this exercise not shown due to space limitations. 
testable hypotheses; a possibility embraced by the author of the present paper. Following these hypotheses, it shows that the broadness of the taxable base indeed seems to have a positive influence on the revenue of the state. But it is important to ask the question (conveniently avoided by Buchanan and Brennan) of what is happening with the proceeds and should the state really be considered a "Leviathan", unaccountable to its citizens. The analysis shows that tax progression and larger tax base seem to be associated with higher satisfaction with life as a whole by the citizens of European countries yet decrease satisfaction with the effectiveness of the national government. The author proposes a simple explanation, independent of the State-as-Leviathan model. It suggests that the simplicity of the tax rules are highly regarded by citizens when evaluating the government. As for life satisfaction and its determinants, it seems that a broad tax base, in line with the propositions of the so-called "orthodox" theories is able to decrease incentive distortions and, at the same time, raise more revenue for the government to pursue socially beneficial goals. Progression, in line with the proposals of the State-as-Leviathan model, is able to decrease social loss from taxation and increase the satisfaction of citizens. In terms of the proportionality of the income tax rate, the literature seems to confirm the results presented in the paper (Oishi et al. 2012). Unfortunately, the link between the broadness of the tax-base and life satisfaction (or for that matter, satisfaction with the government) seems not to be tested yet. Hence, the results of this paper should be treated as preliminary and subject to further testing.

In terms of the limitations of the approach, the most prominent one is the somewhat arbitrary nature of the main independent variable (proxy for the broadness of the tax base). As it uses all tax instruments utilized in all the countries subject to analysis, one has to remember that different instruments directly affect different parts of the population, so even correcting for their decreasing marginal influence may not be sufficient to avoid data biases. The second main area of concern includes the traditional problem with determining the direction of the causal relationship using the OLS tool. It may be the case that governments in countries with populations showing higher satisfaction with life as a whole tend to exploit that fact by introducing more tax instruments. All in all, the results should be considered preliminary and subject to more research.

\section{References}

[1] Apolte, T. 2007, Why Brennan and Buchanan are wrong (after all), IOB Discussionpapier.

[2] Brennan G., Buchanan J.M. 2000, The Power to Tax. Analytical Foundations of a Fiscal Constitution, Liberty Fund, Indianapolis. 
[3] Cameron D.R. 1978, The expansion of the public economy: A comparative analysis, "American Political Science Review" 72, pp. 1243-1261.

[4] Campbell C.D. 1994, New Hampshire's tax-base limits: an example of the Leviathan model, "Public Choice" 78, pp. 129-144.

[5] Deacon R.T. 1979, The expenditure effect of alternative public supply institutions, "Public Choice" 34, pp. 184-192.

[6] La Manna M., Slomp G. 1994, Leviathan: revenue maximize or glory seeker?, "Constitutional Political Economy" Vol. 5, Issue 2, pp. 159-172.

[7] Mehay S.L. 1984, The effect of governmental structure on special district expenditures, "Public Choice" 44, pp. 339-348.

[8] Mueller D. 2003, Public Choice III, Cambridge University Press, Cambridge.

[9] Musgrave R.A. 1959, The Theory of Public Finance, McGraw-Hill Book Company, New York.

[10] Nelson M.A. 1986, An empirical analysis of state and local tax structure in the context of the Leviathan model of government, "Public Choice" 49, pp. 231-262.

[11] Niskanen W. 1971. Bureaucracy and representative government, Transaction Publishers, Chicago.

[12] Oates W.E. 2003. Searching for Leviathan: An Empirical Study, "The American Economic Review", Vol. 75, No. 4, pp. 748-757.

[13] Oishi S., Schimmack U., Diener E. 2012. Progressive Taxation and the Subjective Well-Being of Nations, "Psychological Science" 23, pp. 796-804.

[14] Rawls J. 1971. A Theory of Justice, Harvard University Press, Cambridge.

[15] Rodden J. 2003. Reviving Leviathan: Fiscal Federalism and the Growth of Government, "International Organization" 57, pp. 695-729.

[16] Samuelson P. 1947. Foundations of Economic Analysis, Harvard University Press, Cambridge.

[17] Santolini R. 2009. Leviathan and legislative monopoly power: empirical evidence from OECD countries, "Società italiana di economia pubblica working paper", no. 635.

[18] Schneider M. 1986, Fragmentation and the growth of local government, "Public Choice" 48, pp. 255-263. 